GLOBAL JOURNAL OF PURE AND APPLIED SCIENCES VOL. 21, 2015: 191-195

COPYRIGHT@ BACHUDO SCIENCE CO. LTD PRINTED IN NIGERIA ISSN 1118-0579 www.globaljournalseries.com, Email: info@globaljournalseries.com

\title{
SCHOOL-BASED SURVEY OF ADOLESCENTS' OPINION ON PREMARITAL SEX IN SELECTED SECONDARY SCHOOLS IN YAKURR LOCAL GOVERNMENT AREA, CROSS RIVER STATE, NIGERIA
}

IDANG N. OJONG, CATHERINE N. CHIOTU, EMON U. DUKE AND VICTORIA K. UKA

(Received 18 September 2015; Revision Accepted 26 October 2015)

\begin{abstract}
Purpose: The study examined adolescents' opinion on premarital sex in selected secondary schools in Yakurr Local Government Area of Cross River State.

Method: A cross sectional descriptive survey design was used. The sample size was 313 senior secondary school students from four public secondary schools in Yakurr Local Government Area of Cross River State. Simple random sampling technique was used to select 313 students from 4 schools in Yakurr Local Government Area. Instrument for data collection was a structured questionnaire with a reliability coefficient of 0.79 using Cronbach's Alpha coefficient reliability method. For the data analysis chi square test analysis and independent t-test analysis were used to test the association and differences between variables at $\mathrm{P}<0.05$ significant level.
\end{abstract}

Result: The result showed a non statistical association between adolescents' age on opinion on pre-marital sex when the $X^{2}$ calculated of 1.3 was lesser than $X^{2}$ critical of 3.841 with 1 degree of freedom. The result also revealed that there was no significant difference between gender and opinion on pre marital sex with calculated $t=.324$, critical $t=$ 1.96 df $311, P<0.05$.

Conclusion/recommendation: The result showed a negative relationship between adolescents' age and gender on opinion on premarital sex. Based on these findings, the study suggests intensive awareness programme on premarital sex to be carried out in schools for these adolescents that are at risk of exposure to pre marital sex.

KEYWORDS: Adolescents, opinion, premarital sex.

\section{INTRODUCTION}

Premarital sex is increasing at an alarming rate especially among adolescents. Today the difference between love and sex seems to disappear with most young lovers ending up exploring each other's physique and ultimately unprotected sexual intercourse results. The rise in premarital sex in Africa has resulted in a sexual revolution that came within western culture (Scott, 2009). Premarital sexual exposure is an issue of health concern in many parts of South Eastern Nigeria. Sex in South West Nigeria before now was regarded as sacred and limited to adult males and females within marriage (Alo \& Akinde 2009). Public opinions polls have consistently shown that premarital sex is wrong and dangerous to health, resulting in abortions, teenage mothers and sexually transmitted infections (Alo, 2009).

Nigeria is a relative conservative country, the topic sex is still considered a taboo between parents and children. The adolescents learned through the mass media and peers unguided. Adolescents learned the important topic of sex education in negative manners, rather than having proper sex socialization at home and or in schools (Ojong, Ojong-Alasia \& Samson-Akpan 2014).

Premarital sex is not confined to adolescent alone, a good number of people who are not married are also vulnerable to premarital sex. This is evidenced by the large number of unintended/unwanted pregnancies. Many of which get terminated through unsafe abortions (Crimes, 2010). Early sexual debut, which is most of the time premarital is associated with high risk sexual behaviour in later life (Ojong, Akpan, Ojong-Alasia \& Nlumanze 2014). Multiple sexual partners, high risk of acquiring sexually transmitted infections and an increasing number of girls dropping out of school due to

Idang N. Ojong, Department of Nursing Science, University of Calabar, Cross River State, Nigeria

Catherine N. Chiotu, Nursing Services Department, University of Abuja Teaching Hospital, Abuja, Nigeria

Emon U. Duke, Department of Nursing Science, University of Calabar, Cross River State, Nigeria

Victoria K. Uka, Department of Nursing Science, University of Calabar, Cross River State, Nigeria 
unwanted/unintended pregnancies are associated with early sexual debut (Bukar et al. 2013). A number of youths in South East Nigeria do not see the consequences of premarital sex as serious problems because of misconceptions about sexuality. They initiate early sexual debut and continued to seek abortion with unqualified physicians where unsafe methods are used (Ojong \& Samson-Akpan, 2011).

Owing to these problems generated from premarital sex, several measures have been adopted to avert these by health care providers, government and non-governmental organizations. Inspite of these, there is still clear evidence that sensitization does not achieve the desired impact. This informed the need to carryout this study.

\section{Opinions of adolescents about premarital sex}

An opinion is a belief or judgement not founded on complete knowledge. It is therefore what organizes individual perceptions of the world and guides his behaviour (Umoh, 2010). Studies by Chikowve et al. (2008) in Zimbabwe about youths opinions on premarital sex, using 556 adolescents age 12 - 18years showed that they lack knowledge about sexual and reproductive matters. They rather cherished a number of myths about sex. Also in a study conducted by Ezenduka, (2011) on premarital sex opinion among youth in Enugu, the study listed some myths held by adolescents about sex and pregnancy to include; the beliefs that, pregnancy could not happen the first time that one is exposed to sexual intercourse, that a little sex is good and that spermatozoa from two different men could cancel out each other. According to a study on unmet reproductive health needs and health seeking behaviour of adolescents in Owerri Okereke (2010), using 486 students ages 11 - 19 years, the result showed that young people disregarded virginity which is a cherished norm and gave the opinion that a woman who has reached between 16 and 18 years and is still a virgin is uncivilized person who is either ugly or possess repulsive characteristics that nauseate men.

On the other hand, youths who were against premarital sex gave different opinions from above. According to Family Research Council, (2011) young people value sexual abstinence. The fact that many teens are practising abstinence is not surprising Cremin (2009), since most teens view abstinence favourably. From the above, it was discovered that, majority of the respondents recommended that a strong message from the society on abstinence from sex will help to remedy the situation. Also in agreement to the above Bello, (2010), discovered that $70 \%$ of respondents agreed with the above and also listed the benefits of reproductive health education to include prevention of unwanted pregnancies and abortion, prevention of sexually transmitted infections with HIV/AIDS.

\section{Influence of gender on premarital sex}

Gender is a term that can be used to categorize the different roles of men and women as determined by the society in which they lived, while a person's sex is the biological distinction of being male or female (Adeoye et al. 2012). In a study conducted by Ojong et al. (2014), on gender and sexual behaviour the study showed that males were more likely than females to report engagement in sexual intercourse, male adolescents were of the opinion that affection is not considered a precursor to sexual intimacy than the adolescent females. In a survey by Abiodun, (2013), on race and gender differences and role of sexual attitude in adolescents sexual behaviour; using 5,000 adolescents, males reported more permissive attitudes towards casual sex and extra marital sex compared to females. Males also reported lower levels of anxiety, fear of guilt associated with premarital sexual relations than women. In a study on the issue on premarital sexual relationship among teens in South West Nigeria (Owoaje \& Uchendu, 2009), the study revealed that majority of the female respondents $70 \%$ believed that having sex is just expression of love and girls have sex to be loved. Females gave all in the name of love to establish the truth of reality of their love.

About sexual initiation before marriage among adolescents, a study conducted by Potdar \& Mmari (2010), in India with 386 students, results revealed that more females than males prefer later ages of sexual debut for both males and females. Also approximately $57 \%$ of males in the study agreed that if a boy spends money on a girl, she should have sex with him, while only $31 \%$ of the girls agreed. This calls for parents to initiate early sexuality education for adolescents to avoid early sexual debut.

Specifically, the study is aimed at:

$>$ Assessing the opinions of the adolescents about premarital sex in Yakurr Local Government Area.

$>$ Examining the influence of adolescents gender on opinions about premarital sex in Yakurr Local Government

\section{Research hypotheses}

$>$ There is significant influence between adolescent age and adolescents' opinion on premarital sex in Yakurr Local Government Area.

$>$ Gender does not significantly influence adolescents' opinion on premarital sex in Yakurr Local Government Area

\section{Significance of the study}

It is hoped that the result of the study will be significant to guidance counsellors in schools who may see the need to organize seminars to these students on premarital sex. Furthermore, it is hope that the study result will be of immense benefit to other researchers who may want to improve on this study.

\section{Research design}

The study design was a cross sectional descriptive survey which was school based.

\section{Setting of the study}

The study was carried out in Yakurr which is situated in Central Senatorial District of Cross River State and it is one of the 18 Local Government Area of Cross River State. There are 13 public secondary 
schools in the Local Government. It is bounded in the north by Obubra, South by Adim east by Abi and west by Oban Hills.

\section{Study of population}

The total population of the 4 selected schools was 1244 students.

\section{Sample and sampling technique}

Simple random sampling technique was used to select 313 students used for the study, $26.2 \%$ of the total population was used.

\section{Instrument for data collection}

The validated tested instruments was subjected to a test retest whose reliability coefficient of 0.79 was obtained using Cronbach's alpha coefficient reliability test for internal consistency. The scores was appropriate, hence the instrument was reliable.

\section{Data analysis}

Data generated were organized and entered on statistical package for social sciences (SPSS) version 20. Scores on responses were related as positive and negative. A scores above 20 points was rated as positive opinion, while scores below 10 were rated as negative opinion. Data were analysed using chi square test analysis and independent t-test at $P<0.05$ level of significant.

\section{Research ethics}

Administrative permit was obtained from chairman of secondary schools board to use the 4 schools. Written and informed consents was obtained from the principals to use the students for the study. the purpose of the study was explained to the students. The students were assured of confidentiality and participation was voluntary.

\section{Limitation of the study}

The study was concerned with premarital sex, expressions on these sensitive issues brought about variations which could not be controlled.

RESULTS

Socio-demographic data $-\mathrm{n}=\mathbf{3 1 3}$

TABLE 1: Socio-demographic data of adolescents $n=313$

\begin{tabular}{|l|l|l|l|}
\hline S/No & Variables & Frequency & Percentage \\
\hline 1. & Sex & & \\
& Male & 137 & 42.8 \\
& Female & 176 & 56.2 \\
\hline & Total & 313 & 100 \\
\hline 2. & Age & & \\
& $11-14$ years & 140 & 44.7 \\
& $15-19$ years & 173 & 55.3 \\
\hline & Total & 313 & 100 \\
\hline 3. & Classes & & \\
& SS 1 & 67 & 21.4 \\
& SS 2 & 98 & 31.3 \\
& SS 3 & 148 & 47.3 \\
\hline & Total & 313 & 100 \\
\hline
\end{tabular}

Table 1 showed that majority $176(56.2 \%)$ were female students, while 137(43.8\%) were males. Majority of the students $173(55.3 \%)$ were between the ages of $15-19$ years, $140(44.7 \%)$ were between the ages of 11 - 14 years. One hundred and forty eight $148(47.3 \%)$ were in SS 3, 98(31.3\%) were in SS 2 and 67(21.4\%) were in SS 1 class.

\section{HYPOTHESES RESULTS}

\section{Research hypothesis 1}

There is no significant influence between adolescents' age and opinion on premarital sex.

To test this hypothesis, chi-square test analysis was used.

TABLE 2: Contingency chi-square analysis of influence of age on opinion on premarital sex in Yakurr Local Government Area $(n=313)$

\begin{tabular}{|l|l|l|l|l|l|l|}
\hline \multirow{2}{*}{ Age } & Opinion about Premarital sex & Total & df & $\mathbf{X}^{2}$ cal & $\mathbf{X}^{2}$ cri \\
\cline { 2 - 8 } & Positive opinion & Negative opinion & & & & \\
\hline $11-14$ years & $85(80)$ & $58(63)$ & 143 & & & \\
\hline $15-19$ years & $90(95)$ & $80(75)$ & 170 & 1 & 1.3 & 3.841 \\
\hline Total & 175 & 138 & 313 & & & \\
\hline
\end{tabular}

Not significant at 0.05 ; level of significant with $1 \mathrm{df}, X^{2}$ cal $=1.3, X^{2}$ critical 3.841 
From Table 2 above, the $X^{2}$ calculated of 1.3 was lesser than $X^{2}$ critical of 3.841 needed for significance at 0.05 level with 1 degree of freedom. This means that there is no significant influence between secondary schools students' age and opinion on premarital sex.

\section{Hypothesis 2}

Gender does not significantly influence adolescents' opinion on premarital sex in Yakurr Local Government Area.

hypothesis.

TABLE 3: Independent t-test analysis of the influence of gender on adolescents' opinion on premarital sex in Yakurr Local Government Area $(n=313)$

\begin{tabular}{|l|l|l|l|l|l|}
\hline Gender & $\mathbf{N}$ & $\mathbf{X}$ & $\mathbf{S D}$ & $\mathbf{t}$ & Sig. of t. \\
\hline Male & 137 & 18.35 & 2.04 & & \\
\hline & & & & -.324 & .747 \\
\hline Female & 176 & 18.43 & 2.07 & & \\
\hline Total & 313 & 18.39 & 2.05 & & \\
\hline \multicolumn{7}{r}{ Not significant at 0.05 level of significance; df = 311 $\mathrm{t}=1.96$}
\end{tabular}

The information in Table 3 showed that the calculated t-value of -.324 was less than the critical tvalue of 1.96 needed for significance at 0.05 level of significance with 311 degrees of freedom. This means that the opinion of male and female adolescents in premarital sex do not significantly differ. Hence gender does not influence adolescents' opinion on premarital sex in Yakurr Local Government Area.

\section{DISCUSSION}

The result in testing hypothesis one revealed that there was no significant influence between adolescent's age and their opinion towards premarital sex. The adolescent in the two groups have negative opinions towards premarital sex. The result is in line with -Chikowve et al (2008) also which study's showed lack of knowledge about sexual and reproductive matters among respondents studied. Also in support to the above, Ezenduka (2011), listed some myths held by adolescents about premarital sex. On the other hand, youths who were against premarital sex gave different opinions from the above (family research council 2011).

Analysis of the second hypothesis revealed that gender does not influence adolescents opinion on premarital sex in Yakurr Local Government Area, that boys and girls were relatively of the same opinion that teenage should not indulge in risky sexual behaviour. This result is contrary to the study conducted by Abiodun, (2013), on "race and gender differences" which showed that males were reported to have more permissive attitude on acceptance of casual sex and extra martial sex as compared to females. Also males were reported being anxious, fearless and not guilty of the act than females. From the result, the two groups have been exposed to information on premarital sex.

\section{CONCLUSION AND RECOMMENDATIONS}

Based on the results, the finding showed a non significant influence between adolescents in two age groups and opinion on premarital sex. Adolescent males were not significantly different from adolescent females on their opinion towards premarital sex. The researchers recommended that joints effort by parents, health workers counselors, teachers and government should be intensified on reproductive health awareness for adolescents.

Implication for nursing practice and future research Intensive awareness campaign is advocated for adolescents on dangers of premarital sex and further investigations is indicated to determine the possible factors influencing adolescents' opinion on premarital sex in Cross River State.

\section{Conflict of interest}

The authors declare that they have no competing interest

\section{REFERENCES}

Abiodun, O. A., 2013. HIVIAIDS related sexual behaviours among commercial motorcyclist in Sagamu, South East Nigeria. Int. J. Med. Biomed Res., 2, (3): $69-74$.

Adeoye, A. O., Ola, A and Aliu, B., 2012. Prevalence of premarital sex and factors influencing it among students in a private tertiary institution in Nigeria. International Journal of Psychology and Counselling, 4, (1): $6-9$.

Alo, O. A and Akinde, I. S., 2009. Premarital activities in urban society of South West Nigeria. WAJN, 19: $(2)-10-16$.

Alo, O. A., 2009. Socio-economic determinant of unintended pregnancies among Yoruba women of Southwest, Nigeria. International Journal of Sustainable Development, 1, (4): 145 - 154.

Bello, R. R., 2010. "Parent-child conflict in sexual values. Journal of Social Issues, 22, (2): 34 44.

Bukar, M., Audu, B. M., Kawuwa, M. B., Ibrahim, S. M and Ali, F., 2013. Determinants of premarital sex 
in Maiduguri, Nigeria: Implication for Human Papilloma Virus Vaccination: Int. J. Med. Biomed. Res. 2, (3): $195-201$.

Chikowve, J. Nystron, L., Lindmark, G and Ahlberg, B. M. 2008. Denial and violence paradoxes in men's perspective to premarital sex and pregnancy in rural Zimbabwe in African Sociological Review, $7(1) 53-63$.

Cremin, I. Mushat, P., Mu Pambireyi, Z and Nyamilkpa, C., 2009. Measuring trends in age at first and age at marriage in Manicaland Zimbabwe: Sex Transm Infect., 85, (1): $34-40$.

Crimes, D. A., 2010. Unsafe abortion: The preventable pandemic: Sexual and reproductive Health Journal, 20(1), 9 - 12.

Eruekar, A and Ferede, A., 2009. Social exclusion and early or unwanted sexual initiation among poor females in Ethiopia. Int. perspect reprod Health, 35, (6): $186-193$.

Ezenduka, E. E., 2011. Teenage pregnancy and adolescents gyneacology. A guide for the clinician. New York: Plenum media. 98 - 118.

Family Research Council; Issues analysis: "Why wait., 2011. The benefit of abstinence with marriage". wwwfrccorg/get.cfm.

Ojong, I. N and Samson-Akpan, P. E., 2011. Reproductive Health awareness among secondary school students in Cross River State: Calabar Counsellor (Caljocan) Journal of Counselling Association of Nigeria, 5(5), 146 152.

Ojong, I. N., Akpan, M. I., Ojong-Alasia, $M$ and Nlumanze, F. F., 2014. A comparative study on reproductive health awareness among urban and rural secondary school students in CRS, Nigeria. Journal of Research in Nursing and Midwifery, 3, (1): 21 - 25.

Ojong, I. N., Ojong-Alasia, M and Samson-Akpan, P. E., 2014. Influence of gender and school location on sexual behaviours among secondary school students in Southern Cross River State, Nigeria. Achieves of Applied Science Research, 6, (1): 127 - 130.

Okereke, C. I., 2010. "Unmet reproductive health needs and health seeking behaviour of adolescents in Owerri". African Health Journal of Reprod. Health, 14, (1): 34-43.

Owoaje, E. T and Uchendu, O. C., 2009. Sexual risk behaviour of street youths in South West Nigeria. East Afr. J. Public Health, 6, (1): 274 279.

Potdar, R and Mmari, K., 2010. Factors influencing condom use among male and female youths in Pune India. Glob Public Health, 19, (6): 1 - 16.
Scott, T., 2009. Premarital sex: Almost everyone is doing it. New York: The Associated Press. P. $201-209$.

Umoh, O. A., 2010. Human production and teenage pregnancy. Ibadan: University Press. 126 141. 